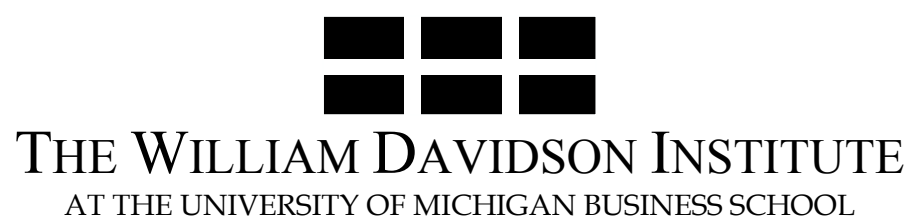

AT THE UNIVERSITY OF MICHIGAN BUSINESS SCHOOL

So Many Rocket Scientists, So Few Marketing Clerks: Occupational Mobility in Times of Rapid Technological Change

By: Nauro F. Campos and Aurelijus Dabušinskas

William Davidson Working Paper Number 552

March 2003 


\title{
So Many Rocket Scientists, So Few Marketing Clerks: Occupational Mobility in Times of Rapid Technological Change
}

\author{
Nauro F. Campos \\ Department of Economics, University of Newcastle, \\ CEPR, London, and Davidson Institute at the University of Michigan. \\ E-mail: n.f.campos@ncl.ac.uk \\ Aurelijus Dabušinskas \\ CERGE-EI, Charles University, Prague. \\ E-mail: aurelijus.dabusinskas@cerge-ei.cz
}

This draft: July 2002

\begin{abstract}
The transition from centrally planned to market economy involves a process of massive occupational change that has been largely neglected in the literature. This paper investigates this process using data from the 1995 Estonian Labour Force Survey. We find that between 35 and 50 percent of wage earners changed occupations from 1989 to 1995 and that job tenure is a consistently important determinant of occupational mobility. Our results also show the speed with which the market mechanism takes root: the returns to current and alternative occupations play, over these few years, increasingly important roles in explaining occupational change.
\end{abstract}

Keywords: Occupational Mobility, Human Capital, Transition Economies.

JEL classification: J62, J63, J64, J23, C41, H53.

The authors thank Tim Barmby, Peter Dolton, Nandini Gupta, Jan Kmenta, Hartmut Lehmann, Jan van Ours, James Robinson, Klara Sabirianova, Daniel Seidmann, Michale Spagat, Jan Svejnar, Katherine Terrell, Andrey Timofeev, Jonathan Wadsworth and seminar participants at the Universities of London, Michigan, Newcastle and Reading, CERGE-EI (Prague), CEPR/ZEI Workshop on Labour Markets in Transition (Riga), ESRC/DESG Annual Meetings (Nottingham), CEPR/WDI Conference on Transition Economics (Portoroz), LACEA Meetings (Montevideo) and Royal Economic Society Meetings (Warwick) for comments on earlier versions. We are thankful for data assistance from Mare Zaneva, Aavo Heinlo, Peter Luke and Kaja Söstra. This paper benefited from financial support from the European Commission's Phare ACE Grant P97-8085. The usual disclaimer applies. 


\section{Introduction}

One of the few positive legacies from socialism is the high level of educational attainment of the labour force. In spite of it, the composition of the stock of human capital (in terms of occupations) has proven inadequate to the needs of a modern market economy. The transition from central planning to market economy entails a process of massive occupational change that has been largely neglected in the literature. This paper attempts to fill this gap.

We offer three motivations. The process of economic development in general, and that of transition in particular, necessarily involves occupational change. One of the least appreciated features of Lewis' seminal surplus labour model is that it is not sufficient for workers to move from the rural to the urban sector, they must change occupations. Campos and Coricelli (forthcoming) summarize the first ten years of the transition in a set of seven stylized facts. One of these facts is that labour moved. Although workers did not seem to have moved geographically, they changed sectors and occupations in unprecedented scale. In order to comprehend the process of economic development in general, and that of transition in particular, we need to grasp the process of occupational change. A second motivation for studying occupational mobility is that it can throw light on the recent debate on the skill premium. ${ }^{1}$ One argument in this debate is that rising wage inequality in the last two decades in the U.S., U.K. and Canada is due to skill-biased technological change. Studying occupational mobility may be useful because one of its determinants is the transferability of skills across occupations. In this light, the premium may have risen for skills that are more easily transferable. A third and final motivation is that occupational change is at the heart of the allocation of talent problem. Murphy, Schleifer and Vishny (1991) and Acemoglu and Verdier (1998) emphasise that one of the most important aspects of the process of accumulation of human capital regards occupational choice. In particular, how society's pool

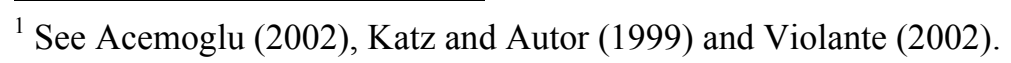


of talent is allocated to entrepreneurial or rent-seeking activities is of fundamental importance vis-à-vis long-term growth. Murphy et al. (1991) put forward empirical evidence showing that countries with a larger proportion of engineers grow faster than countries with a larger proportion of lawyers.

The objective of this paper is twofold. The first is to provide a detailed description of the changing composition of the stock of human capital (in terms of the occupational mix), and the second is to investigate the determinants of this process of occupational change. We choose Estonia for a number of reasons. Foremost is that the Estonian Labour Force Survey is arguably the best database in the region. It is unique as it contains a retrospective section with detailed information on work histories that go back to communist times (until 1991, Estonia was one of the Soviet Republics). Also, among transition economies, Estonia is considered a radical reformer and as such has pursued aggressive labour market policies that have fostered mobility.

There are very few studies on occupational mobility. Shaw $(1984,1987)$ models the relationship between occupational change, sunk costs of occupational investment and transferability of skills. She tests the model using data for young men (aged 14-24) during the period 1966 to 1975 in the United States. McCall (1990) and Sicherman and Galor (1990) investigate occupational change in a matching framework. Dolton and Kidd (1998) provide an empirical analysis of occupational mobility of recent graduates in Great Britain from 1980 to 1987. Overall, these studies tend to focus on "careers" (that is, upward occupational mobility) and the attendant empirical evidence favours young men. In contrast, our paper covers the entire age distribution and deals with downward as well as upward occupational mobility. In terms of the literature on transition economies, our paper is closer to Sabirianova's study of occupational mobility in Russia (2000). There are at least two important differences. Sabirianova investigates the consequences of occupational mobility in late transition Russia 
(1994-1998). In contrast, this paper emphasizes the determinants of occupational mobility and it does that before and in the very early years of the transition. ${ }^{2}$

We use data from the Estonian Labour Force Survey 1995 (hereafter, ELFS95), a representative survey of Estonian workers covering the period from 1989 to 1995. The data cover the end of the socialist period as well as the early years of the transition to a market economy. Depending on the level of aggregation used to classify occupations, we find that between 35 and 50 percent of all Estonian wage earners changed occupations in this short period of time. ${ }^{3}$ Moreover, the bulk of these occupational switches happened in the early years, that is, at the very beginning of the transition. We find that job tenure is the main determinant of occupational mobility: it has a negative, significant and robust impact from 1989 to 1994 . Our results also show the remarkable speed with which the market mechanism takes root: the returns to current and alternative occupations play, over these few years, increasingly meaningful roles in explaining occupational change. For instance, the effect of the returns to the current occupation only gradually becomes statistically significant and of the expected sign (higher returns to the current occupation lower the probability of changing occupations). This same gradual emergence happens to returns to alternative occupations. Moreover, we find that these results are robust to the effects of gender, ethnicity, labour market conditions, heterogeneity of workers and complexity of the occupational switch.

The paper is organized as follows. The next section documents the process of occupational change in the Estonian transition. Section 3 presents the econometric model we

\footnotetext{
${ }^{2}$ The data available for Estonia do not allow us to provide a detailed discussion of the impacts nor to cover the late transition period (the latter is not an important shortcoming as the vast majority of occupational switches take place in the first two years of transition).

${ }^{3}$ Sabirianova (2000) reports that about 30 percent of Russian workers changed occupations from 1991 to 1995, and Campos and Zlabkova (2001) also find that approximately 30 percent of Hungarian workers changed occupations from 1989 to 1995. Note these results refer to the two-digit classification of occupations. Shaw, focusing solely on young men in the United States between 1966 and 1975, reports that "on average, 54 percent of the sample changed their 3-digit occupation, and 41 percent changed their 1-digit occupation, over the two-year intervals" (1984, p. 329). Parrado and Wolff (1999) find that "45\% of adult males changed 1-digit occupation between 1972 and 1974."
} 
use to investigate the determinants of this process and discusses the steps taken to test it empirically, with emphasis on the construction of our key variables. Section 4 examines the determinants of occupational mobility during the transition from centrally planned to market economy. Section 5 concludes.

\section{Data and measurement}

The objective of this section is to describe the changing composition of the stock of Estonian human capital with emphasis on its occupational shares. The main data source is the Estonian 1995 Labour Force Survey (ELFS95), which contains data on education, occupation, residence and family background. The ELFS95 is often described as wider than a normal labour force survey because it also includes a retrospective section, covering the period 19891995, that has wage data as well as information on work histories.

The sampling procedure uses the 1989 Census to randomly draw one of every 100 persons in the 16-75 age group in 1995. Of 10,955 people selected, 9,608 were interviewed. ${ }^{4}$ Respondents reported employment status monthly throughout the period, but reported wages only in the Fall of 1989, 1992, 1993 and 1994. From the outset, the high inflation years of 1990 and 1991 were excluded. All the variables are coded following the latest standard international classifications: occupations were coded according to ISCO, education to ISCED and economic activity according to ISIC. Because economic reforms started in 1991 (which is the year of independence from the USSR), the data cover two years before the start of transition and three to four years into it.

\footnotetext{
${ }^{4}$ The difference is given by the following motives: failure to locate (557 people), emigration (404), death or illness (130), or refusal to participate (213) (Eamets, Kulikov and Philips, 1997).
} 
The ELFS95 was prepared and carried out paying particular attention to the well-know difficulties with retrospective data. ${ }^{5}$ The retrospective responses regarding employment status were compared to the 1989 Census data. Most of the small discrepancies found could be explained by differences in the definition of the labour force. Although wage data could not be directly compared, the sample means of wages in the ELFS95 match wage data from the Estonian Statistical Office for all years (Noorkôiv et al., 1998). Last, but not least, data on economic activity and occupation were re-coded to the Soviet classification and the results were found to compare satisfactorily to the 1989 Census (Eamets et al., 1997).

Let us now turn to measuring the extent of occupational mobility in Estonia. The ELFS95 provides up to four-digit ISCO-88 occupation codes. The incidence of occupational mobility can be observed and analyzed at any of these four possible levels of aggregation, but the decision about the level of aggregation at which occupational mobility is to be studied involves a trade-off. On the one hand, we might want to capture as many incidences of occupational change as possible and perform the investigation in terms of four-digit groupings. On the other, we might want to minimise measurement error by focusing on occupational shifts using broader definitions of occupations. The literature traditionally focuses on two-digit occupations and thus we emphasise this level in what follows.

Table 1 shows our results for the available four different levels of aggregation. Not surprisingly, the incidence of occupational mobility decreases with the level of aggregation. For example, gross occupational flows based on four-digit coding indicate that 47.1 percent of individuals who were employed in both 1988 and 1995 have changed occupations. This share declines to 35.2 percent if we use one-digit occupational grouping. Similar differences can be found in the yearly rates of change. Notice that the differences across levels of aggregation do not seem large at first sight because they also reflect the differences between the flows

\footnotetext{
${ }^{5}$ See Beckett et al. (2001).
} 
occurring "within groups" and "between groups." For example, consider the difference between the rates of gross occupational flows of 9 percent and 8.4 percent in 1990-1991 obtained from four- and three-digit coding, respectively. If not caused by measurement error, 0.6 percentage point difference may be due to the occupational mobility within three-digit groups. Net occupational flows in Table 1 take into account only those changes of occupations that simultaneously alter the structural composition of occupations. In other words, the net measures neglect those parts of between-group flows that cancel out. It can be seen that depending on the level of aggregation and year, the net flows account for 37 to 12 percent of gross flows. The results in Table 1 also suggest that the importance of net flows in gross flows has a peak early followed by an inverse-U shape dynamics. The peak years of 1991-93 were associated with the most extensive changes in the occupational structure. ${ }^{6}$

While these results demonstrate that occupational change was rather impressive in the early Estonian transition, it says little about the nature of these changes. How extensive were these changes? It is important to investigate whether or not those workers changing occupations also changed firm and sector. Complex changes are defined as those in which workers change simultaneously occupation and firm (Neal, 1999). We find that between 1989 and 1995, 69.1 percent of all occupational switches are complex according to this definition. ${ }^{7}$ It is also worth noting that the share of complex switches rises rapidly in the first years of transition.

Table 2 describes the occupational dynamics from the ELFS95 sample in terms of one-digit level occupations. It shows that four out of nine occupational groups have contracted during the transition in Estonia. These include plant and machine operators, clerks, professionals, and craft and related trade workers. Interestingly, the share of service workers

\footnotetext{
${ }^{6}$ Note, however, that these net flows do not characterize structural changes fully. For example, inflows into and outflows from employment that caused structural shifts in occupations are not taken into account (Haltiwanger and Vodopivec, 2000).
} 
Table 1

Measuring Occupational Mobility in Estonia, 1989-1995

\begin{tabular}{|c|c|c|c|c|}
\hline Period & $\begin{array}{c}\text { Gross } \\
\text { Occupational } \\
\text { Flows, } \%\end{array}$ & $\begin{array}{c}\text { Net } \\
\text { Occupational } \\
\text { Flows, } \%\end{array}$ & $\begin{array}{c}\text { Share of Net } \\
\text { Flows in Gross, } \\
\%\end{array}$ & $\begin{array}{c}\text { Number of } \\
\text { observations }\end{array}$ \\
\hline \multicolumn{5}{|c|}{ Four-Digit ISCO88 Codes } \\
\hline 1988-1989 & 5.1 & - & - & 5906 \\
\hline 1989-1990 & 8.2 & - & - & 6049 \\
\hline 1990-1991 & 9.0 & - & - & 5911 \\
\hline 1991-1992 & 13.4 & - & - & 5461 \\
\hline $1992-1993$ & 15.3 & - & - & 5187 \\
\hline 1993-1994 & 13.6 & - & - & 5140 \\
\hline $1988-1995$ & 47.1 & - & - & 4379 \\
\hline \multicolumn{5}{|c|}{ Three-Digit ISCO88 Codes } \\
\hline 1988-1989 & 4.7 & 1.5 & 31.5 & 5906 \\
\hline 1989-1990 & 7.6 & 2.3 & 30.5 & 6049 \\
\hline $1990-1991$ & 8.4 & 3.1 & 37.1 & 5911 \\
\hline 1991-1992 & 12.5 & 4.2 & 33.8 & 5461 \\
\hline $1992-1993$ & 14.3 & 4.6 & 32.2 & 5187 \\
\hline 1993-1994 & 12.7 & 2.9 & 23.3 & 5140 \\
\hline $1988-1995$ & 44.0 & 17.1 & 38.8 & 4379 \\
\hline \multicolumn{5}{|c|}{ Two-Digit ISCO88 Codes } \\
\hline 1988-1989 & 4.4 & 1.0 & 23.3 & 5906 \\
\hline 1989-1990 & 6.9 & 1.4 & 20.8 & 6049 \\
\hline $1990-1991$ & 7.5 & 2.1 & 27.4 & 5911 \\
\hline 1991-1992 & 11.5 & 3.0 & 26.5 & 5461 \\
\hline $1992-1993$ & 12.9 & 3.7 & 29.0 & 5187 \\
\hline 1993-1994 & 11.6 & 1.8 & 15.7 & 5140 \\
\hline 1988-1995 & 40.3 & 14.3 & 35.4 & 4379 \\
\hline \multicolumn{5}{|c|}{ One-Digit ISCO88 Codes } \\
\hline 1988-1989 & 3.7 & 0.8 & 21.1 & 5906 \\
\hline 1989-1990 & 5.9 & 1.1 & 18.7 & 6049 \\
\hline 1990-1991 & 6.5 & 1.2 & 17.7 & 5911 \\
\hline 1991-1992 & 9.9 & 2.2 & 21.9 & 5461 \\
\hline $1992-1993$ & 11.0 & 2.8 & 25.9 & 5187 \\
\hline 1993-1994 & 10.0 & 1.2 & 11.9 & 5140 \\
\hline 1988-1995 & 35.2 & 10.0 & 28.4 & 4379 \\
\hline $\begin{array}{l}\text { Note: Gross occu } \\
\text { different occupat } \\
\text { individuals empl } \\
\text { values of change } \\
\text { International Stan }\end{array}$ & $\begin{array}{l}\text { 1n December of } t \\
\text { occupational shar } \\
\text { Classification of }\end{array}$ & $\begin{array}{l}\text { ated as a ratio of th } \\
\text { ent year and in De } \\
\text { base year. Net flo } \\
\text { or all occupations } \\
\text { upations (Internatio }\end{array}$ & $\begin{array}{l}\text { number of employed } \\
\text { mber of a base year } \mathrm{t} \\
\mathrm{s} \text { are computed by s } \\
\text { nd dividing by two. } \\
\text { al Labour Office, } 199\end{array}$ & $\begin{array}{l}\text { dividuals who had } \\
\text { he total number of } \\
\text { ming the absolute } \\
\text { CO88 is the } 1988\end{array}$ \\
\hline
\end{tabular}

\footnotetext{
${ }^{7}$ Yearly estimates are not reported for the sake of space but are available from the authors upon
} request. 
and salesmen as well as that of senior officials and managers has expanded. This is perhaps what one should expect. Note, however, that elementary occupations have also gained importance. One possible interpretation is that the economic transformation has forced a number of workers to move to lower-skill jobs. The last row ("extensiveness of change") confirms our previous result that 1992 and 1993 were the years of most intense change in the occupational structure.

After considering the magnitude and complexity of occupational switches, we now turn to their direction. Is the average switch one from occupations that require lots of schooling to ones that require little? Is the average switch one from high earnings occupations to ones with low earnings? In order to answer these questions we must first rank occupations. To do so, we construct two rankings: one is derived from an index of the amount of human capital needed for different occupations and the other based on pure monetary returns. ${ }^{8}$ Although the correlation between the results from the two rankings is high ( 0.87 at the twodigit level for year 1994), there are important differences. In particular, the ranking of occupations by schooling requirement shows very little change from 1989 to 1994, while the ranking of occupations by earnings shows enormous changes. Once each occupational switch is classified according to their direction up or down these two rankings, we find that about half of the switches are movements down the schooling ladder and thus there is little that can be said conclusively. Yet for the case of the earnings ladder, we find that the majority of the occupational changes involve moving down the ranking. ${ }^{9}$

\footnotetext{
${ }^{8}$ We use the methodology proposed by Sicherman and Galor (1990, pp. 189-192). The "schooling ladder" is based on a Mincerian regression. First, we regress log wage on dummy variables for sector of activity, for level of education, for location, for gender, and experience and experience squared. The schooling coefficients are used as weights to average the occupational means. Similarly, the "earnings ladder" is derived by regressing log wages on dummy variables for sector of activity, for level of education, for location, for gender, experience and experience squared, and dummies for occupation. Second, the occupation coefficients are used as the indexes.

${ }^{9}$ Further details are available from the authors upon request.
} 
Table 2

The Extent of Occupational Mobility in Estonia, 1989-1995: Percentage Change of Occupational Shares

\begin{tabular}{|c|c|c|c|c|c|c|c|c|c|c|}
\hline & $\begin{array}{l}\text { Share } \\
1989, \\
\%\end{array}$ & 1989 & 1990 & 1991 & 1992 & 1993 & 1994 & 1995 & $\begin{array}{l}1988- \\
95\end{array}$ & $\begin{array}{l}\text { Share } \\
1995, \\
\%\end{array}$ \\
\hline & \multicolumn{10}{|c|}{ Change in shares, $\%$} \\
\hline Armed forces & 0.1 & -26.7 & 18.2 & 7.7 & 0.0 & 78.6 & 12.0 & 14.3 & 113.3 & 0.32 \\
\hline $\begin{array}{l}\text { Legislators, senior } \\
\text { officials and managers }\end{array}$ & 11.5 & -1.4 & 0.3 & 0.8 & 6.1 & 6.4 & 1.4 & 1.3 & 15.4 & 13.4 \\
\hline Professionals & 13.6 & -1.8 & -1.8 & -2.5 & 2.4 & -4.0 & -4.2 & 3.0 & -8.8 & 12.6 \\
\hline $\begin{array}{l}\text { Technicians and associate } \\
\text { professionals }\end{array}$ & 10.9 & -0.1 & -1.7 & 0.8 & 1.3 & 5.0 & 0.6 & -1.8 & 4.0 & 11.4 \\
\hline Clerks & 5.8 & -3.3 & -0.9 & 2.4 & -1.5 & -4.5 & -4.7 & 2.5 & -9.8 & 5.4 \\
\hline $\begin{array}{l}\text { Service workers, shop and } \\
\text { market sales workers }\end{array}$ & 7.1 & 2.3 & 3.5 & 1.5 & 14.9 & 18.1 & 7.0 & -1.6 & 53.8 & 10.6 \\
\hline $\begin{array}{l}\text { Skilled agricultural and } \\
\text { fishery workers }\end{array}$ & 4.3 & -0.2 & 5.9 & 2.4 & 5.0 & -9.1 & 4.5 & 3.0 & 11.2 & 4.8 \\
\hline $\begin{array}{l}\text { Craft and related trade } \\
\text { workers }\end{array}$ & 21.7 & 1.7 & -0.4 & 0.1 & -2.3 & -5.1 & -1.5 & -0.1 & -7.4 & 19.7 \\
\hline $\begin{array}{l}\text { Plant and machine } \\
\text { operators }\end{array}$ & 17.4 & -0.6 & -1.3 & -2.0 & -10.0 & -10.0 & -4.8 & -2.1 & -27.4 & 12.7 \\
\hline Elementary occupations & 7.7 & 3.5 & 3.2 & 1.1 & -2.5 & 10.6 & 6.4 & -2.1 & 21.4 & 9.1 \\
\hline Extensiveness of change & & 1.9 & 1.8 & 1.3 & 4.3 & 7.7 & 3.6 & 1.7 & 15.8 & \\
\hline $\begin{array}{l}\text { Note:First and last columns (Sha } \\
\text { The middle columns ("Change i } \\
\text { occupational shares. The categor } \\
\text { the extent of the changes: it is th }\end{array}$ & in 198 & nd 199 & the abs & rcent & of chan & inners & ach o & pation & $\begin{array}{l}\text { total e } \\
\text { centage } \\
\text { f chang }\end{array}$ & $\begin{array}{l}\text { loyment. } \\
\text { anges in } \\
\text { captures }\end{array}$ \\
\hline
\end{tabular}


In summary, in this section we have provided some direct evidence of the process of massive occupational change in which between 35 and 50 percent of all employed Estonian workers changed occupations in half a decade. The bulk of these occupational switches happened very early in the transition. We also found that the average or typical change of occupations involved stepping down the earnings ladder. In the next sections, we go beyond description and try to identify the main determinants of this process of occupational change.

\section{Econometric model}

In this paper we use a modified version of a standard model for the study of occupational mobility. Shaw's 1987 model states that the probability of changing between occupations $i$ and $j$ and/or employers $d$ and $e$ at time $t$ is given by:

$$
p_{t}^{\mathrm{ij}, \mathrm{de}}=\beta_{1} \operatorname{COST}_{\mathrm{t}}^{\mathrm{i}, \mathrm{j}}+\beta_{2} \operatorname{RTN}_{\mathrm{t}}^{\mathrm{i}}+\beta_{3} \operatorname{RTN}_{\mathrm{t}}^{\mathrm{j}}+\beta_{4} \operatorname{TENURE}_{\mathrm{t}}^{\mathrm{d}}+\boldsymbol{\beta}_{5} \mathbf{X}_{\mathbf{i}}+\varepsilon_{\mathrm{t}}^{\mathrm{i}, \mathrm{j}}
$$

where COST represents the value of lost returns to past occupational investment, $\mathrm{RTN}^{\mathrm{i}}$ is the present value of occupational investment in the current occupation, $\mathrm{RTN}^{\mathrm{j}}$ is the present value of occupational investment in an alternative occupation, TENURE proxies for the level of current employer-specific investment, and $\mathbf{X}$ contains a set of variables to control for sector of activity, firm ownership (state, cooperative, private) and location (town or country) of initial employment. This last set of variables plays the crucial role of mitigating omitted variables bias as they account for important features of the transition from plan to market, in particular, the relative decline of certain industries (manufacturing) and certain sectors (the public sector). 
Shaw's model predicts that an increase in the present value of occupational investment in the current occupation reduces the probability of changing occupations, while an increase in the present value of occupational investment in an alternative occupation has the opposite effect. The increase in the value of lost returns to past occupational investments and an increase in job tenure both are likely to reduce the likelihood of switching occupations.

Although the intuition from this model is relatively straightforward, the construction of its main variables is clearly not. Let us start describing in some detail how we construct the returns to current and alternative occupations. These returns are estimated from a standard Mincerian wage regression for every year for which wage data were available (that is 1989, 1992, 1993, and 1994). Returns to current occupation results from a regression of log wage on gender, level of education (seven categories), sector of activity, firm ownership, firm location, occupation dummies, age, and occupation dummies interacted with age. We use two-digit occupational codes. The returns to current occupation are calculated as the sum of the coefficient on the occupational dummy with the coefficient on age interacted with the relevant occupation times the age of the worker.

The returns to alternative occupations are computed as the weighted average of the returns to all other occupations where weights are the probability of actual occupational switches in the previous period. For example, when calculating current and alternative returns in 1989, we use actual occupational switches between 1988 and 1989 to obtain these probabilities. The same procedure was followed for all other years, with the exception of the returns for 1990 and 1991, for which, as noted, wage data is unavailable.

In addition, returns to current and alternative occupations were calculated on the basis of current and future wages. The fundamental difference is with respect to the information taken into account for the decision to change occupations. Current returns (to current and alternative occupations) are calculated using current wages, while future returns (to current and alternative 
occupations) assume that workers can forecast wages and thus use this information for deciding whether or not to change occupations. We try to minimise endogeneity concerns by computing occupational switches using the first as the current year (for example, we use 1989 to compute occupational switches in 1990). The intuition is that workers would know current and alternative returns from 1989 wages and decide whether or not to change occupations in 1990. Returns to current and alternative occupations on a future basis are constructed using 1992 wages for occupational mobility in the years 1989, 1990 and 1991. For the year 1992 we use wages of 1993, and for the year 1993 we use wages of 1994.

One of the most difficult variables in the model is the value of lost returns to past occupational investment. The literature recognizes these difficulties and the standard solution seems to be to try to empirically capture its inverse. We follow Shaw (1987) in arguing that the latter can be satisfactorily proxied by those skills in the current occupation that can be transferred easily across occupations. In this light, a number of "skills transferability indexes" (STI) have been proposed in the literature. ${ }^{10}$ Unfortunately, our data does not allow to replicate any of these indexes and we were forced to propose an alternative. We tried several possibilities $^{11}$ and decided for the following:

\footnotetext{
${ }^{10}$ See, e.g., the skills transferability indexes used by Shaw (1987), Sicherman and Galor (1990) and Sabirianova (2000).

${ }^{11}$ One index we tried was to compute, for each qualification, the share of individuals holding the qualification but working outside the "main" occupation. The main occupation here was defined as the occupation employing the greatest number of people with that qualification. An alternative we also experimented with was to use the relative number of occupational categories covered by those holding a particular qualification. Because both of these indexes have normalization problems, we decided that the alternative discussed above was preferable.
} 


$$
\begin{aligned}
& S T I_{q}=1-\frac{\sum_{j=1}^{J}\left(N_{q, j}-\frac{N_{q}}{J}\right)^{2}}{N_{q}^{2}} \text {, where } \\
& J-\text { number of occupation categories, } \\
& N_{q} \text {-total number of persons with qualification } q, \\
& N_{q, j}-\text { number of persons with qualification } q \text { in occupation } j .
\end{aligned}
$$

where $J$ is the number of occupational categories, $N_{q}$ is the number of workers with qualification $q$, and $N_{q, j}$ is the number of workers with qualification $q$ in occupation $j$. This index is equal to 1 if the qualification is uniformly distributed across occupational categories and the value of the index declines if the qualification is not uniformly distributed (that is, if the qualification is more concentrated in some occupations). When ranking two-digit qualifications, our skills transferability index (STI) does a good job in singling out secondary and basic education as the two most easily transferable qualifications and in identifying home economics and theology as those qualifications that are most difficult to transfer across occupations.

In summary, our econometric model posits that the probability of switching occupations is a positive function of the returns to alternative occupations and of the transferability of the skills used in the current occupation. It also proposes that the probability of switching occupations is an inverse function of the returns to the current occupation and of job or firm tenure. Let us now turn to the results.

\section{The Determinants of Occupational Mobility}

The objective of this section is to investigate the determinants of occupational mobility in Estonia over the period 1989-1995. Table 3 shows our probit estimates of equation (1) using 
returns calculated on the basis of current wages (Panel A) as well as returns calculated on the basis of future wages (Panel B).

The one result that stands out as statistically significant for all years in the two panels is that for job or firm tenure. This is measured as the number of years the worker has spent with the current employer and our results show that this significantly lowers the probability of changing occupations. It is important to notice that this result obtains controlling for initial sector of employment, initial firm ownership, initial firm location and education level. Unfortunately, neither our STI (skills transferability index) nor our measure of potential labour market experience play a systematic role in explaining occupational mobility.

Some of the most striking results from Table 3 are those relating to the returns to current and alternative occupation. Panel A shows the stark contrast between the results for 1990 and those for 1994. Recall that, for 1990, the data still refer to the Soviet Republic of Estonia or, in other words, it refers to the probability of switching occupations in the socialist system. Indications of rationality as we know it in a market economy are to be mistrusted. The sign on the coefficient on returns to alternative occupations suggests that, during communism in Estonia, an increase in those returns actually decreases the probability of switching occupations. Maybe workers could observe the erosion of the relative returns to their current occupation, but they could not react. In stark contrast we show the results for 1994, after some years of deep economic reform. It can be seen that the coefficient on the returns to current occupation is now statistically significant and carries the sign theory predicts: a decrease in these returns (everything else the same) translates into an increase of the probability of changing occupations. Notice that the coefficient on the returns to alternative occupation is now statistically significant and carries the predicted sign. An improvement in the outside 
Table 3

Determinants of Occupational Mobility in the Estonian Transition

(Probit estimates)

\section{Panel A: Returns based on current wages}

$\begin{array}{lccc} & 1990 & 1993 & 1994 \\ \text { Returns to current } & -.009 & -.025 & -.053^{*} \\ \text { occupation } & .018) & (.034) & (.028) \\ \text { Returns to alternative } & -.087^{* * *} & -.023 & .148^{* * *} \\ \text { occupation } & (.025) & .037) & (.051) \\ \text { Skills transferability } & -.013 & -.018 & -.023 \\ \text { index } & (.017) & (.021) & (.019) \\ \text { Dummy: Female=1 } & -.017 * * & -.015 & -.035^{* * *} \\ & (.006) & (.009) & (.009) \\ \text { Experience } & .162^{* *} & .029 & -.184^{* * *} \\ & (.079) & (.152 & (.063) \\ \text { Firm tenure } & -.277^{* * *} & -.251 * * * & -.229^{* * *} \\ & (.045) & (.062) & (.068) \\ \text { Log likelihood } & -1385.37 & -1686.69 & -1552.11 \\ \text { Number of observations } & 5843 & 4894 & 4751\end{array}$

Panel B: Returns based on future wages

\begin{tabular}{|c|c|c|c|c|c|}
\hline & 1990 & 1991 & 1992 & 1993 & 1994 \\
\hline Returns to current & .025 & -.019 & -.036 & .021 & -.036 \\
\hline occupation & $(.021)$ & $(.022)$ & $(.03)$ & $(.03)$ & $(.023)$ \\
\hline Returns to alternative & $-.05 * * *$ & .029 & .054 & .068 & $.091 * *$ \\
\hline occupation & $(.018)$ & $(.024)$ & $(.036)$ & $(.051)$ & $(.044)$ \\
\hline Skills transferability & -.014 & $-.04 * * *$ & .005 & -.02 & -.024 \\
\hline index & $(.017)$ & $(.015)$ & $(.022)$ & $(.021)$ & $(.019)$ \\
\hline \multirow[t]{2}{*}{ Dummy: Female $=1$} & $-.012 *$ & $-.03 * * *$ & -.005 & -.012 & $-.03 * * *$ \\
\hline & $(.006)$ & $(.007)$ & $(.009)$ & $(.009)$ & $(.009)$ \\
\hline \multirow[t]{2}{*}{ Experience } & .042 & $-.17 * *$ & -.177 & -.088 & $-.29 * * *$ \\
\hline & $(.087)$ & $(.09)$ & $(.129)$ & $(.071)$ & $(.048)$ \\
\hline \multirow[t]{2}{*}{ Firm tenure } & $-.28 * * *$ & $-.21 * * *$ & $-.17 * * *$ & $-.26 * * *$ & $-.23 * * *$ \\
\hline & $(.046)$ & $(.049)$ & $(.059)$ & $(.062)$ & $(.069)$ \\
\hline Log likelihood & -1388.4 & -1421.3 & -1719.9 & -1686.5 & -1553.5 \\
\hline Number of observations & 5843 & 5685 & 5259 & 4894 & 4751 \\
\hline \multicolumn{6}{|c|}{$\begin{array}{l}\text { Note: Not shown: dummies for education (primary, basic, secondary, specialized secondary, higher and academic } \\
\text { degree), for sector (primary, secondary and tertiary), for ownership (private, state and co-operative), and for } \\
\text { location (town and countryside). Wage data for } 1991 \text { and } 1992 \text { were not collected because these were years of } \\
\text { high inflation. Occupational mobility basis for comparison is "not switching" (assigned value } 0 \text { ). } \\
\text { Standard errors (in parentheses) are heteroscedastic-consistent, *** denotes significant at the } 1 \% \text { level; } \\
* * \text { denotes significant at the } 5 \% \text { level; and * denotes significant at the } 10 \% \text { level. }\end{array}$} \\
\hline
\end{tabular}


option increases the probability of changing occupations. We believe that these results show the remarkable speed with which the market mechanism takes root: the returns to current and alternative occupations play, over these very few years, increasingly meaningful roles in explaining occupational change. One of the most commonly alleged reasons for studying transition economies is that they provide a natural laboratory for observing the gradual emergence of a market mechanism. This difficult and complex issue is what Table 3 shows in succinct fashion.

For the first and last years of the two panels, the dummy variable for gender is statistically significant and suggests that, after taking into account a number of important determinants, females are still less likely than males to change occupations. Notice that the gender effect is not statistically significant over all years. Given the importance of gender differences with respect to occupational choice, we deem that the issue deserves a closer analysis. $^{12}$

Another concern regards ethnicity issues. Estonia is, among the Baltic countries, the one with the largest Russian minority (as of late 1990s, only about two-thirds of the population are of Estonian origin). Kroncke and Smith (1999) offer econometric evidence that suggests that labour market discrimination in favour of Estonian nationals increased significantly throughout the transition. One would thus expect that Estonian nationality would significantly affect the probability of changing occupation.

Table 4 assesses these gender and ethnicity issues for the case of returns to current and alternative occupations on the basis of current wages, splitting the sample by gender. There is a very interesting result, namely, that the process of occupational mobility seems to be driven by radically different reasons for men and women (with the exception of tenure that remains a

\footnotetext{
${ }^{12}$ The effects of private ownership of the firm changes signs over time (from negative to positive) and that may be a reflection of transition itself. Initially, if a worker was initially in the private sector perhaps he or she was less likely to move than if in the state sector. Yet later on, it is the private sector that constitutes the larger part of economy, so movers would tend to be from the private sector.
} 
crucial determinant irrespectively). While, for males, the main determinant seems to be that the negative effect of the returns to current occupation pushes them to change occupations, for females our results suggest that the fundamental issue is that the returns to alternative occupations seem to drive them to change occupations. These results are not inconsistent with the notion that the transition has been good to women by favouring sectors and occupations in which they do well in advanced market economies. Our results suggest that occupational mobility is driven by push factors for males and by pull factors for women, once the market mechanism starts to take root (that is for years 1993 and 1994 in Table 4). Notice that these results also hold taking into account the effect of ethnicity (although the latter is not found to be a systematic determinant). ${ }^{13}$

Table 5 shows our gender and ethnicity results for the case of returns on the basis of future wages. Firm tenure is, once again, the main determinant of occupational mobility. The results for our skills transferability index show that its coefficient is seldom statistically significant (for males) and it changes sign often. Notice, however, that using future wages as a basis to calculate returns confirms the previous results for the males sub-sample that their process of occupational mobility is driven (after the start of economic reforms) by declining returns to current occupation. Yet, the pull factor result for women looses statistical significance when we use future wages to calculate returns. The effect of Estonian ethnicity is still not statistically significant.

Another area of concern is whether or not our results are robust to the incorporation of labour market conditions and of worker heterogeneity issues. In order to address the first issue, we use a number of variables, such as regional (county) employment rates. This addition does not change the basic results discussed above. Our results are also robust to the introduction of various controls for worker heterogeneity. More specifically, they do not

\footnotetext{
${ }^{13}$ We tried a dummy variable for whether or not Estonian is the main language spoken at home and the results are not qualitatively different.
} 
Table 4

Determinants of Occupational Mobility in the Estonian Transition (Probit estimates): Sensitivity Analysis Using Returns based on Current Wages to Assess Gender and Ethnicity Issues

\begin{tabular}{|c|c|c|c|}
\hline \multicolumn{4}{|l|}{ Panel A: Males } \\
\hline & 1990 & 1993 & 1994 \\
\hline Returns to current & -.0293 & $-.11 * *$ & $-.11 * * *$ \\
\hline occupation & $(.031)$ & $(.04)$ & $(.041)$ \\
\hline Returns to alternative & $-.147 * * *$ & .031 & .099 \\
\hline occupation & $(.039)$ & $(.05)$ & $(.071)$ \\
\hline Skills transferability & $-.462 * *$ & .014 & $-.054 * *$ \\
\hline index & $(.023)$ & $(.031)$ & $(.027)$ \\
\hline \multirow[t]{2}{*}{ Experience } & $.351 * * *$ & .043 & $-.301 * * *$ \\
\hline & $(.107)$ & $(.223)$ & $(.105)$ \\
\hline \multirow[t]{2}{*}{ Firm tenure } & $-.354 * * *$ & $-.278 * * *$ & $-.273 * * *$ \\
\hline & $(.069)$ & $(.092)$ & $(.097)$ \\
\hline \multirow[t]{2}{*}{ Dummy: Estonian=1 } & -.008 & $.028 * *$ & $.034 * *$ \\
\hline & $(.010)$ & $(.014)$ & $(.014)$ \\
\hline Log likelihood & -740.15 & -948.95 & -910.49 \\
\hline Number of observations & 2979 & 2603 & 2534 \\
\hline \multicolumn{4}{|l|}{ Panel B: Females } \\
\hline & 1990 & 1993 & 1994 \\
\hline \multirow{2}{*}{$\begin{array}{l}\text { Returns to current } \\
\text { occupation }\end{array}$} & .001 & .059 & .015 \\
\hline & $(.022)$ & $(.047)$ & $(.039)$ \\
\hline \multirow{2}{*}{$\begin{array}{l}\text { Returns to alternative } \\
\text { occupation }\end{array}$} & -.013 & $.088^{*}$ & $.156^{* *}$ \\
\hline & $(.032)$ & $(.051)$ & $(.066)$ \\
\hline \multirow{2}{*}{$\begin{array}{l}\text { Skills transferability } \\
\text { index }\end{array}$} & .022 & $-.049^{*}$ & .012 \\
\hline & $(.027)$ & $(.028)$ & $(.026)$ \\
\hline \multirow[t]{2}{*}{ Experience } & -.064 & .074 & -.062 \\
\hline & $(.108)$ & $(.211)$ & $(.091)$ \\
\hline \multirow[t]{2}{*}{ Firm tenure } & $-.195 * * *$ & $-.228 * * *$ & $-.193 * *$ \\
\hline & $(.060)$ & $(.081)$ & $(.089)$ \\
\hline \multirow[t]{2}{*}{ Dummy: Estonian=1 } & -.008 & .007 & .018 \\
\hline & $(.009)$ & $(.013)$ & $(.012)$ \\
\hline Log likelihood & -624.58 & -718.99 & -623.88 \\
\hline Number of observations & 2849 & 2285 & 2197 \\
\hline \multicolumn{4}{|c|}{$\begin{array}{l}\text { Note: Not shown: dummies for education (primary, basic, secondary, specialized secondary, higher and a } \\
\text { degree), for sector (primary, secondary and tertiary), for ownership (private, state and co-operative), } \\
\text { location (town and countryside). Wage data for } 1991 \text { and } 1992 \text { were not collected because these were } \\
\text { high inflation. Occupational mobility basis for comparison is "not switching" (assigned value } 0 \text { ). } \\
\text { Standard errors (in parentheses) are heteroscedastic-consistent, } * * * \text { denotes significant at the } 1 \% \text { level; } \\
* * \text { denotes significant at the } 5 \% \text { level; and * denotes significant at the } 10 \% \text { level. }\end{array}$} \\
\hline
\end{tabular}


Table 5

Determinants of Occupational Mobility (Probit estimates):

Sensitivity Analysis Using Returns based on

Future Wages to Assess Gender and Ethnicity Issues

\begin{tabular}{|c|c|c|c|c|c|}
\hline \multicolumn{6}{|l|}{ Panel A: Males } \\
\hline & 1990 & 1991 & 1992 & 1993 & 1994 \\
\hline Returns to current & $.054 *$ & -.037 & $-.096 * *$ & $-.084 *$ & $-.109 * * *$ \\
\hline occupation & $(.031)$ & $(.034)$ & $(.040)$ & $(.044)$ & $(.032)$ \\
\hline Returns to alternative & $-.097 * * *$ & .047 & .064 & .075 & .061 \\
\hline occupation & $(.026)$ & $(.035)$ & $(.047)$ & $(.071)$ & $(.068)$ \\
\hline Skills transferability & $-.049 * *$ & -.038 & .022 & .007 & $-.053^{*}$ \\
\hline index & $(.024)$ & $(.023)$ & $(.030)$ & $(.031)$ & $(.027)$ \\
\hline Experience & $\begin{array}{c}.126 \\
(.122)\end{array}$ & $\begin{array}{l}-.211 \\
(.137)\end{array}$ & $\begin{array}{l}-.011 \\
(.181)\end{array}$ & $\begin{array}{l}-.307 * * * \\
(.115)\end{array}$ & $\begin{array}{c}-.258 * * * \\
(.065)\end{array}$ \\
\hline Firm tenure & $\begin{array}{c}-.365 * * * \\
(.070)\end{array}$ & $\begin{array}{c}-.314 * * * \\
(.076)\end{array}$ & $\begin{array}{c}-.149 * * \\
(.086)\end{array}$ & $\begin{array}{c}-.271 * * * \\
(.092)\end{array}$ & $\begin{array}{c}-.259 * * * \\
(.097)\end{array}$ \\
\hline Dummy: Estonian=1 & $\begin{array}{l}-.008 \\
(.010)\end{array}$ & $\begin{array}{l}.004 \\
(.011)\end{array}$ & $\begin{array}{l}.017 \\
(.012)\end{array}$ & $\begin{array}{l}.027^{*} \\
(.014)\end{array}$ & $\begin{array}{l}.033 * * \\
(.014)\end{array}$ \\
\hline Log likelihood & -743.55 & -839.75 & -926.35 & -950.02 & -908.24 \\
\hline Number of observations & 2979 & 2947 & 2784 & 2603 & 2534 \\
\hline \multicolumn{6}{|l|}{ Panel B: Females } \\
\hline & 1990 & 1991 & 1992 & 1993 & 1994 \\
\hline \multirow{2}{*}{$\begin{array}{l}\text { Returns to current } \\
\text { occupation }\end{array}$} & -.010 & -.011 & .018 & $.121 * * *$ & .052 \\
\hline & $(.029)$ & $(.029)$ & $(.046)$ & $(.042)$ & $(.033)$ \\
\hline \multirow{2}{*}{$\begin{array}{l}\text { Returns to alternative } \\
\text { occupation }\end{array}$} & -.0002 & .016 & .048 & .013 & .081 \\
\hline & $(.0301)$ & $(.034)$ & $(.048)$ & $(.072)$ & $(.061)$ \\
\hline \multirow{2}{*}{$\begin{array}{l}\text { Skills transferability } \\
\text { index }\end{array}$} & .022 & $-.037 *$ & -.013 & $-.049 *$ & .009 \\
\hline & $(.027)$ & $(.019)$ & $(.031)$ & $(.028)$ & $(.026)$ \\
\hline \multirow[t]{2}{*}{ Experience } & -.052 & -.101 & $-.322 *$ & .104 & $-.288 * * *$ \\
\hline & $(.114)$ & $(.119)$ & $(.173)$ & $(.107)$ & $(.063)$ \\
\hline \multirow[t]{2}{*}{ Firm tenure } & $-.191 * * *$ & $-.109 *$ & $-.212 * * *$ & $-.245 * * *$ & $-.203 * *$ \\
\hline & $(.061)$ & $(.062)$ & $(.077)$ & $(.081)$ & $(.089)$ \\
\hline \multirow[t]{2}{*}{ Dummy: Estonian=1 } & -.008 & -.006 & .001 & .005 & .017 \\
\hline & $(.009)$ & $(.009)$ & $(.013)$ & $(.013)$ & $(.012)$ \\
\hline Log likelihood & -624.56 & -573.82 & -783.23 & -715.72 & -624.29 \\
\hline Number of observations & 2849 & 2720 & 2467 & 2285 & 2197 \\
\hline \multicolumn{6}{|c|}{$\begin{array}{l}\text { Note: Not shown: dummies for education (primary, basic, secondary, specialized secondary, higher and academic } \\
\text { degree), for sector (primary, secondary and tertiary), for ownership (private, state and co-operative), and for } \\
\text { location (town and countryside). Occupational mobility basis for comparison is "not switching" (assigned value } \\
\text { 0). Standard errors (in parentheses) are heteroscedastic-consistent, *** denotes significant at the } 1 \% \text { level; } \\
* * \text { denotes significant at the } 5 \% \text { level; and * denotes significant the } 10 \% \text { level. }\end{array}$} \\
\hline
\end{tabular}


change if we include, as an explanatory variable, the number of occupations previously held, number of jobs previously held, the age of the individual, a dummy variable for multiple-job holding, the yearly number and the cumulative number of jobs lost, and number of months of non-employment in the year of reference (up to a maximum of 11 months). ${ }^{14}$

Finally, one last important form of sensitivity analysis is to investigate whether the results presented above are robust in light of occupational switches of different levels of complexity. As before, a complex occupational switch is defined as a simultaneous change of occupation and firm (Neal, 1999). In Table 6 we estimate a multinomial logit model to identify the main factors that discriminate between intra- and inter-firm occupational mobility (Sicherman and Galor, 1990). The three possible states in this exercise are to change occupation and firm, to change occupation but stay in the same firm, and to not change occupation (but the worker may still change firm in this last case). The latter state is the reference category. As noted above, about $60 \%$ of the occupational switches we observe are complex.

The results from Table 6 show the importance of the complexity of occupational switches as the results discussed above seem to be driven by inter-firm mobility. Recall that a complex switch is when we observe changes of occupation and sector simultaneously. ${ }^{15}$ Notice that the results for inter-firm mobility in Table 6 are qualitatively the same as the results discussed above. Our multinomial logit estimates show that the dummy variable for females carries a negative sign and is statistically significant for all years and the same happens to the coefficient on firm tenure. Our skills transferability index does not seem to play a systematic role in explaining the complexity of occupational switches. Also notice the gradual change in the

\footnotetext{
${ }^{14}$ Notice that for a job lost we only consider the cases in which the reason for dismissal was one of the following: closing of enterprise, reorganisation of enterprise, bankruptcy of enterprise, privatisation of enterprise, dismissal initiated by the employer, and personnel reduction. These results are available from the authors on request.

${ }^{15}$ We tested for the irrelevance of independent alternatives (IIA) using the Hausman and Small-Hsiao tests and both indicate that the design we chose is appropriate.
} 
coefficients on the returns to current and alternative occupations, suggesting that this is a robust finding.

As noted, our data does not allow for a rich study of the effects of occupational mobility as we have few impact variables that we can use. One of the few results we can generate regards the impact of occupational mobility on wage growth. Occupational mobility is found to hinder wage growth (data available only for 1993 and 1994). ${ }^{16}$

\footnotetext{
${ }^{16}$ Further details are available from the authors on request.
} 
Table 6

Determinants of Occupational Mobility (Multinomial Logit);

Sensitivity Analysis Using Returns based on Future Wages to Assess Complexity (Intra- and Inter-firm mobility)

\begin{tabular}{|c|c|c|c|c|c|c|c|c|c|c|}
\hline & \multicolumn{2}{|c|}{1990} & \multicolumn{2}{|c|}{1991} & \multicolumn{2}{|c|}{1992} & \multicolumn{2}{|c|}{1993} & \multicolumn{2}{|c|}{1994} \\
\hline & $\begin{array}{c}\text { Interfirm } \\
\text { mobility }\end{array}$ & $\begin{array}{c}\text { Intrafirm } \\
\text { mobility }\end{array}$ & $\begin{array}{l}\text { Interfirm } \\
\text { mobility }\end{array}$ & $\begin{array}{c}\text { Intrafirm } \\
\text { mobility }\end{array}$ & $\begin{array}{l}\text { Interfirm } \\
\text { mobility }\end{array}$ & $\begin{array}{c}\text { Intrafirm } \\
\text { mobility }\end{array}$ & $\begin{array}{c}\text { Interfirm } \\
\text { mobility }\end{array}$ & $\begin{array}{c}\text { Intrafirm } \\
\text { mobility }\end{array}$ & $\begin{array}{l}\text { Interfirm } \\
\text { mobility }\end{array}$ & $\begin{array}{c}\text { Intrafirm } \\
\text { mobility }\end{array}$ \\
\hline Returns to current occupation & $\begin{array}{c}.379 \\
(.411)\end{array}$ & $\begin{array}{c}.143 \\
(.691)\end{array}$ & $\begin{array}{l}-.302 \\
(.395)\end{array}$ & $\begin{array}{c}-.829 \\
(.781)\end{array}$ & $\begin{array}{l}-.296 \\
(.363)\end{array}$ & $\begin{array}{c}-1.114 \\
(.794)\end{array}$ & $\begin{array}{c}.158 \\
(.347)\end{array}$ & $\begin{array}{c}.311 \\
(.714)\end{array}$ & $\begin{array}{c}-.505 * * \\
(.272)\end{array}$ & $\begin{array}{l}-.096 \\
(.745)\end{array}$ \\
\hline Returns to alternative occupation & $\begin{array}{c}-1.14 * * * \\
(.343)\end{array}$ & $\begin{array}{c}.146 \\
(.553)\end{array}$ & $\begin{array}{c}.385 \\
(.441)\end{array}$ & $\begin{array}{c}1.27 \\
(.869)\end{array}$ & $\begin{array}{c}.35 \\
(.387)\end{array}$ & $\begin{array}{c}2.03 * * \\
(1.02)\end{array}$ & $\begin{array}{c}.545 \\
(.567)\end{array}$ & $\begin{array}{c}1.36 \\
(1.31)\end{array}$ & $\begin{array}{l}1.19 * * \\
(.512)\end{array}$ & $\begin{array}{l}-.784 \\
(1.29)\end{array}$ \\
\hline Skills transferability index & $\begin{array}{l}-.006 \\
(.322)\end{array}$ & $\begin{array}{l}-.250 \\
(.701)\end{array}$ & $\begin{array}{c}-.532 * * \\
(.249)\end{array}$ & $\begin{array}{l}-.106 \\
(.658)\end{array}$ & $\begin{array}{c}.077 \\
(.275)\end{array}$ & $\begin{array}{c}.561 \\
(.728)\end{array}$ & $\begin{array}{l}-.272 \\
(.223)\end{array}$ & $\begin{array}{l}.187 \\
(.662)\end{array}$ & $\begin{array}{l}-.238 \\
(.208)\end{array}$ & $\begin{array}{c}.027 \\
(.647)\end{array}$ \\
\hline Dummy: Female=1 & $\begin{array}{c}-.369 * * * \\
(.132)\end{array}$ & $\begin{array}{c}.232 \\
(.221)\end{array}$ & $\begin{array}{c}-.518 * * * \\
(.123)\end{array}$ & $\begin{array}{l}-.145 \\
(.284)\end{array}$ & $\begin{array}{c}-.186^{*} \\
(.107)\end{array}$ & $\begin{array}{l}.468 * * \\
(.221)\end{array}$ & $\begin{array}{c}-.294 * * * \\
(.109)\end{array}$ & $\begin{array}{c}.762 * * * \\
(.251)\end{array}$ & $\begin{array}{c}-.391 * * * \\
(.1146)\end{array}$ & $\begin{array}{l}-.384 \\
(.291)\end{array}$ \\
\hline Experience & $\begin{array}{c}2.059 \\
(1.631)\end{array}$ & $\begin{array}{l}-3.24 \\
(2.83)\end{array}$ & $\begin{array}{l}-2.66^{*} \\
(1.605)\end{array}$ & $\begin{array}{l}-2.44 \\
(2.75)\end{array}$ & $\begin{array}{l}-1.29 \\
(1.49)\end{array}$ & $\begin{array}{c}-5.139 * \\
(2.96)\end{array}$ & $\begin{array}{c}-1.38^{*} \\
(.827)\end{array}$ & $\begin{array}{c}1.59 \\
(1.551)\end{array}$ & $\begin{array}{c}-3.58 * * * \\
(.576)\end{array}$ & $\begin{array}{l}-.551 \\
(1.34)\end{array}$ \\
\hline Firm tenure & $\begin{array}{c}-8.62 * * * \\
(1.24)\end{array}$ & $\begin{array}{r}1.128 \\
(1.36)\end{array}$ & $\begin{array}{c}-5.16 * * * \\
(1.128)\end{array}$ & $\begin{array}{c}.375 \\
(1.368)\end{array}$ & $\begin{array}{c}-3.29 * * * \\
(.794)\end{array}$ & $\begin{array}{c}1.79 \\
(1.29)\end{array}$ & $\begin{array}{c}-4.01 * * * \\
(.804)\end{array}$ & $\begin{array}{c}1.22 \\
(1.27)\end{array}$ & $\begin{array}{l}-3.86 * * * \\
(1.04)\end{array}$ & $\begin{array}{l}-.331 \\
(1.61)\end{array}$ \\
\hline $\begin{array}{l}\text { Log likelihood } \\
\text { Number of observations }\end{array}$ & \multicolumn{2}{|c|}{-1576.84} & \multicolumn{2}{|c|}{-1572.78} & \multicolumn{2}{|c|}{-1961.97} & \multicolumn{2}{|c|}{-1889.21} & $\begin{array}{r}-173 \\
47 \\
\end{array}$ & $\begin{array}{l}0.35 \\
51\end{array}$ \\
\hline $\begin{array}{l}\text { Note: Not shown: dummies for edu } \\
\text { ownership (private, state and co-oper } \\
\text { Interfirm mobility stands for change } \\
\text { Standard errors (in parentheses) are h } \\
\text { level. }\end{array}$ & $\begin{array}{l}\text { ive), and for } \\
\text { occupation an } \\
\text { eroscedastic- }\end{array}$ & $\begin{array}{l}\text { location (tow } \\
\mathrm{d} \text { change in fi } \\
\text { onsistent, } * * *\end{array}$ & $\begin{array}{l}\text { m. Intrafirm } \\
\text { denotes sign }\end{array}$ & $\begin{array}{l}\text { and abroad). } \\
\text { obility stand } \\
\text { icant at the } 10\end{array}$ & or change in & $\begin{array}{l}\text { nobility bas } \\
\text { ccupation in } \\
\text { tes significa }\end{array}$ & $\begin{array}{l}\text { e), for sect } \\
\text { for comparis } \\
\text { ime firm. } \\
\text { at the } 5 \% \text { lev }\end{array}$ & is not swi & significant & $\begin{array}{l}\text { tertiary), for } \\
\text { ons or firms } \\
\text { the } 10 \%\end{array}$ \\
\hline
\end{tabular}




\section{Conclusions}

In this paper, we used data from a representative survey of Estonian workers between 1989 and 1995 (the Estonian Labour Force Survey 1995) to document the process occupational change in detail. We find evidence that this process was massive: according to our estimates, between 35 and $50 \%$ of all employed Estonian workers changed occupations in half a decade. Moreover, the bulk of these occupational switches happened in the first years, that is, very early in the transition. We also find that the typical (average) change of occupations involved stepping down both the schooling and earnings ladders. Because these moves down the ladder meant losses, we suggest that the process of occupational change was driven more by the transition itself (a large number of bad matches need not be anymore) than by individual workers' choice.

We also inquired into the determinants and the consequences of occupational mobility in Estonia. The main findings in this regard are that the main factors lowering the probability of an employed worker changing occupation are gender (female) and having longer experience and longer job tenure. We find that although returns to current or alternative occupations do not seem to play a systematic role, they play over these few years increasingly meaningful roles in explaining occupational change. Regarding its impact, we find that the private costs of occupational mobility have outweighed the benefits (e.g. occupational mobility tend to lower wage growth), reinforcing our conclusions that the massive process of occupational mobility contributed, in the early years, to the costs of transition. 


\section{References}

Acemoglu, Daron, "Technical Change, Inequality, and The Labor Market," Journal of Economic Literature 40 (1): 7-72, 2002.

Acemoglu, Daron and Thierry Verdier, "Corruption, Property Rights and The Allocation of Talent: A General Equilibrium Approach,” Economic Journal 108 (450): 1381-1403, 1998.

Beckett, Megan, Julie Da Vanzo, Narayan Sastry, Constantijn Panis, and Christine Peterson, "The Quality of Retrospective Data: An Examination of Long-Term Recall in a Developing Country," Journal of Human Resources 36(3):593-625, 2001.

Campos, Nauro and Fabrizio Coricelli, "Growth in Transition: What We Know, What We Don't, and What We Should," Journal of Economic Literature, forthcoming.

Campos, Nauro and Dana Žlábková, "The Wrong Mix: A First Look at Occupational Mobility during the Hungarian Transition,” Prague: CERGE-EI DP 59, March 2001.

Dolton, Peter and Michael Kidd, "Job Changes, Occupational Mobility and Human Capital Acquisition: An Empirical Analysis," Bulletin of Economic Research 50 (4), pp. 265-95, 1998.

Eamets, Raul, Kulikov, D., and Kaja Philips (eds), Estonian Labour Force Survey 1995, Structural Changes in the Estonian Labour Market in 1989-1994, Statistical Office of Estonia, Tallinn-Viljandi, 1997.

Haltiwanger, John and Milan Vodopivec, "Gross Worker and Job Flows in a Transition Economy: An Analysis of Estonia," mimeo, University of Maryland, 2000.

Helemäe, J., Saar, E., and R. Vöörmann, "Occupational Mobility in Estonia: What is Changed in 1989-1994?" in Eamets, R.,(ed), Estonian Labour Market and Labour Market Policy, Viljandi-Tallinn, Ministry of Social Affairs of Estonia, 1999.

International Labour Office, ISCO-88: International Standard Classification of Occupations. Geneva: ILO, 1990.

Katz, Lawrence and David Autor, "Changes in the Wage Structure and Earnings Inequality" in Orley Ashenfelter and David Card (eds), Handbook of Labor Economics, vol 3b, Amsterdam: Elsevier, 1999.

Kroncke, Charles and Kenneth Smith, "The Wage Effects of Ethnicity in Estonia," Economics of Transition, 7(1), pp. 179-99, 1999.

McCall, Brian, "Occupational Matching: A Test of Sorts," Journal of Political Economy 90 (1), pp. 45-69, 1990.

Murphy, Kevin, Schleifer, Andrei and Robert Vishny, "The Allocation of Talent: Implications for Growth,” Quarterly Journal of Economics, 503-530, May 1991. 
Neal, Derek, "The Complexity of Job Mobility among Young Men," Journal of Labor Economics 17 (2), pp. 237-261, 1999.

Noorkôiv, R., Orazem, P.F., Puur, A., and M. Vodopivec, "Employment and Wage Dynamics in Estonia," 1989-95, Economics of Transition, 6(2), pp. 481-503, 1998.

Parrado, Eric and Edward Wolff, "Occupational and Industry Mobility in the United States, 1969-1992,” New York University, C.V. Starr Center Report 99-20, November 1999.

Sabirianova, Klara, "The Great Human Capital Reallocation: A Study of Occupational Mobility in Transitional Russia," Ann Arbor, William Davidson Institute WP 309, October 2000 .

Sicherman, Nachum and Oded Galor, “A Theory of Career Mobility," Journal of Political Economy, 98 (1), pp. 169-192, 1990.

Shaw, Kathryn, "A Formulation of the Earnings Function using the Concept of Occupational Investment," Journal of Human Resources 19 (3), 319-340, 1984.

Shaw, Kathryn, "Occupational Change, Employer Change, and the Transferability of Skills," Southern Economic Journal 53 (3), pp 702-719, 1987.

Svejnar, Jan, "Labor Markets in Transitional Central and Eastern European Economies," in Orley Ashenfelter and David Card (eds), Handbook of Labor Economics, vol 3b, Amsterdam: Elsevier, 1999.

Statistical Office of Estonia, Education, Tallinn. Various issues (1990/91, 1992/93 - 1997/98).

Statistical Office of Estonia, Estonian Labour Force Surveys 1995 and 1997. Estonian Labour Force 1989-1997, Statistical Office of Estonia, Tallinn, 1998.

Violante, Giovanni, "Technological Acceleration, Skill Transferability and The Rise in Residual Inequality,” Quarterly Journal of Economics 117 (1): 297-338, 2002.

Weber, R., and G. Taube, "On the Fast Track to EU Accession: Macroeconomic Effects and Policy Challenges for Estonia," Washington D.C., International Monetary Fund, Working Paper 99/156, 1999. 


\section{DAVIDSON INSTITUTE WORKING PAPER SERIES - Most Recent Papers}

The entire Working Paper Series may be downloaded free of charge at: www.wdi.bus.umich.edu

CURRENT AS OF 3/28/03

\begin{tabular}{|c|c|c|}
\hline Publication & Authors & Date \\
\hline $\begin{array}{l}\text { No. 552: So Many Rocket Scientists, So Few Marketing Clerks: } \\
\text { Occupational Mobility in Times of Rapid Technological Change }\end{array}$ & $\begin{array}{l}\text { Nauro F. Campos and Aurelijus } \\
\text { Dabušinskas }\end{array}$ & Mar. 2003 \\
\hline $\begin{array}{l}\text { No. 551: Determinants of Interregional Mobility in Russia: Evidence } \\
\text { from Panel Data }\end{array}$ & $\begin{array}{l}\text { Yuri Andrienko and Sergei } \\
\text { Guriev }\end{array}$ & Feb. 2003 \\
\hline $\begin{array}{l}\text { No. 550: Gross Job Flows in Ukraine: Size, Ownership and Trade } \\
\text { Effects }\end{array}$ & $\begin{array}{l}\text { Jozef Konings, Olga Kupets and } \\
\text { Hartmut Lehmann }\end{array}$ & Mar. 2003 \\
\hline $\begin{array}{l}\text { No. 549: Technology Transfer through FDI in Top-10 Transition } \\
\text { Countries: How Important are Direct Effects, Horizontal and Vertical } \\
\text { Spillovers? }\end{array}$ & $\begin{array}{l}\text { Jože P. Damijan, Mark Knell, } \\
\text { Boris Majcen and Matija Rojec }\end{array}$ & Feb. 2003 \\
\hline $\begin{array}{l}\text { No. 548: Does Foreign Direct Investment Increase the Productivity of } \\
\text { Domestic Firms? In Search of Spillovers through Backward Linkages }\end{array}$ & Beata K. Smarzynska & Mar. 2003 \\
\hline $\begin{array}{l}\text { No. 547: Re-employment Probabilities and Wage Offer Function for } \\
\text { Russian Labor Market }\end{array}$ & Natalia V. Smirnova & Feb. 2003 \\
\hline $\begin{array}{l}\text { No. 546: Democratization's Risk Premium: Partisan and Opportunistic } \\
\text { Political Business Cycle Effects on Sovereign Ratings in Developing } \\
\text { Countries }\end{array}$ & $\begin{array}{l}\text { Steven Block, Burkhard N. } \\
\text { Schrage and Paul M. Vaaler }\end{array}$ & Feb. 2003 \\
\hline $\begin{array}{l}\text { No. 545: Structural Reforms and Competitiveness: Will Europe } \\
\text { Overtake America? }\end{array}$ & Jan Svejnar & Feb. 2003 \\
\hline No. 544: Why the Rich May Favor Poor Protection of Property Rights & Konstantin Sonin & Dec. 2002 \\
\hline $\begin{array}{l}\text { No. 543: Reinvested Earnings Bias, The "Five Percent" Rule and the } \\
\text { Interpretation of the Balance of Payments - With an Application to } \\
\text { Transition Economies }\end{array}$ & $\begin{array}{l}\text { Josef C. Brada and Vladimír } \\
\text { Tomšík }\end{array}$ & Feb. 2003 \\
\hline $\begin{array}{l}\text { No. 542: The Impact of Ownership Reform in Chinese Industry, 1995- } \\
2001\end{array}$ & $\begin{array}{l}\text { Gary H. Jefferson, Su Jian, Jiang } \\
\text { Yuan and Yu Xinhua }\end{array}$ & Feb. 2003 \\
\hline $\begin{array}{l}\text { No. 541: Defensive and Strategic Restructuring of Firms during the } \\
\text { Transition to a Market Economy }\end{array}$ & $\begin{array}{l}\text { Domadenik, Janez Prašnikar and } \\
\text { Jan Svejnar }\end{array}$ & Feb. 2003 \\
\hline No. 540: Tenuous Financial Stability & $\begin{array}{l}\text { Neven T. Valev and John A. } \\
\text { Carlson }\end{array}$ & Feb. 2003 \\
\hline $\begin{array}{l}\text { No. 539: Non-monetary Trade and Differential Access to Credit in the } \\
\text { Russian Transition }\end{array}$ & Vlad Ivanenko & Feb. 2003 \\
\hline $\begin{array}{l}\text { No. 538: International Price-Fixing Cartels and Developing Countries: } \\
\text { A Discussion of Effects and Policy Remedies }\end{array}$ & $\begin{array}{l}\text { Margaret Levenstein and Valerie } \\
\text { Suslow with Lynda Oswald }\end{array}$ & Feb. 2003 \\
\hline No. 537: Foreign Banks in Bulgaria, 1875-2002 & $\begin{array}{l}\text { Kenneth Koford and Adrian E. } \\
\text { Tschoegl }\end{array}$ & Jan. 2003 \\
\hline $\begin{array}{l}\text { No. 536: Forthcoming in Vanderbilt Journal of Transnational Law, } \\
\text { "Healthy Organizations and the Link to Peaceful Societies: Strategies } \\
\text { for Implementing Organizational Change" }\end{array}$ & $\begin{array}{l}\text { Jeannette Jackson and Maria } \\
\text { Coolican }\end{array}$ & Jan. 2003 \\
\hline $\begin{array}{l}\text { No. 535: Forthcoming in Vanderbilt Journal of Transnational Law, } \\
\text { "Workplace Violence and Security: Are there Lessons for } \\
\text { Peacemaking?" }\end{array}$ & $\begin{array}{l}\text { Frances E. Zollers and Elletta } \\
\text { Sangrey Callahan }\end{array}$ & Jan. 2003 \\
\hline $\begin{array}{l}\text { No. 534: Forthcoming in Vanderbilt Journal of Transnational Law, } \\
\text { "700 Families to Feed: The Challenge of Corporate Citizenship" }\end{array}$ & Tara J. Radin & Jan. 2003 \\
\hline $\begin{array}{l}\text { No. 533: Forthcoming in Vanderbilt Journal of Transnational Law, } \\
\text { "Governing for Genuine Profit" }\end{array}$ & Michael J. O'Hara & Jan. 2003 \\
\hline $\begin{array}{l}\text { No. 532: Forthcoming in Vanderbilt Journal of Transnational Law, } \\
\text { "Adapting Corporate Governance for Sustainable Peace" }\end{array}$ & $\begin{array}{l}\text { Timothy L. Fort and Cindy A. } \\
\text { Schipani }\end{array}$ & Jan. 2003 \\
\hline $\begin{array}{l}\text { No. 531: Forthcoming in Vanderbilt Journal of Transnational Law, } \\
\text { "Groundings of Voice in Employee Rights" }\end{array}$ & Dana Muir & Jan. 2003 \\
\hline $\begin{array}{l}\text { No. 530: Forthcoming in Vanderbilt Journal of Transnational Law, } \\
\text { Gender Voice and Correlations with Peace }\end{array}$ & $\begin{array}{l}\text { Morehead Dworkin and Cindy A. } \\
\text { Schipani }\end{array}$ & Jan. 2003 \\
\hline $\begin{array}{l}\text { No. 529: Forthcoming in Vanderbilt Journal of Transnational Law, } \\
\text { "The Organizational Model for Workplace Security" }\end{array}$ & Dr. Thomas K. Capozzoli & Jan. 2003 \\
\hline
\end{tabular}

